\title{
THE OWNER CONSENT STATUTES: THE DISTINCTIONS BETWEEN ENTERPRISE AND INSTRUMENTALITY LIABILITY
}

Courts and legislatures have taken many different approaches to the problem of the financially irresponsible automobile driver. Compulsory insurance and financial responsibility laws have been much discussed. ${ }^{1}$ One chronic problem is the driver of a borrowed car. The owner may have liability insurance, but the driver often will not. In the typical case a friend or a member of the owner's family, perhaps a dependent minor, causes injury by driving the vehicle negligently. Unless the injured plaintiff can get at the owner's assets or liability insurance, he may gain nothing from litigation except an uncollectable judgment. If it can be proved that the owner selected a driver whom he should have known to be incompetent, he is liable under normal negligence concepts. Agency theories and the widely recognized family car doctrine may be helpful. ${ }^{2}$ At least eight states have gone further and attempted to solve the problem by adopting owner consent statutes which make the owner of a motor vehicle liable for the damage caused by the negligence of anyone who drives it with his consent. ${ }^{3}$ The purpose of these

1 See, e.g., Ehrenzweig, Negligence Without Fault (1951); Morris, Torts 340-74 (1953); Vorys, $A$ Short Survey of Laws Designed to Exclude the Financially Irresponsible Driver From the Highway, 15 OHo ST. L. J. $10 \mathrm{l}$ (1954).

2 See 2 Harper and Janes, The Law of Torts $\$ \$ 26.13-26.15$ (1956); Prosser, HANDBOOK OF THE LAW OF TORTS 368-69 (2d ed. 1955). Generally, the family car doctrine makes the owner of an automobile who allows members of his household to drive it liable for their negligence under most circumstances.

3 CAL. Vehicle Code $\$$ 17150-52; D.C. Code tit. 40, $\$ 424$ (1961); IdAho Code tit. 49, $\S \S 1403-04$ (1947); Iowa Code ANN. § 321.493 (1946); Mich. STAt. ANN. § 9.2101 (1960); Minn. Stat. ANN. § 170.54 (1960); N.Y. Vehicle \& Traffic Law \& 388; R.I. GeN. Laws \& 31-33-6 (Supp. 1962). Other states have similar statutes applying only when the driver is a minor under sixteen or eighteen: DEL. CoDE ANN. tit. 21, § 6106 (Supp. 1962); Kan. Gen. Stat. Ann. ch. 8, § 222 (1949); Maine Rev. Stat. ch. 22, § 156 (1954); UtAh Code ANN. \$§ 41-2-10, 41-2-22 (1953); VA. Code tit. 8 § 646.2 (1950). Nevada's consent statute applies only when the driver is a member of the owner's family. NEv. REv. STAT. § $41-440$ (1961).

A closely related problem is presented by the "omnibus clauses" of some automobile owner liability insurance policies. These clauses extend the policy coverage to anyone driving the vehicle with the consent of the owner, and allow the injured plaintiff to sue the insurance company directly. In Massachusetts, all automobile owners are required by law to have liability insurance with such a clause. This amounts to a limited owner consent statute, and presents similar problems. Dickinson v. Great Am. Indem. Co., 296 Mass. 368, 6 N.E.2d 439 (1937). In California such clauses are also compulsory in insurance policies, but owners do not have to have insurance. Curiously, consent is more narrowly construed in the insurance clauses than in the owner consent 
statutes must have seemed clear when they were enacted. The owner who lends his car to a financially irresponsible person is required at his peril to protect the public by purchasing the necessary insurance. If the permittee has the assets to pay a judgment, the owner is protected by a right to recover over from him. ${ }^{4}$ One might have expected that this sweeping statutory owner liability would make the technicalities of agency law irrelevant in almost all automobile personal injury cases. Ironically, however, these technicalities reappeared at once, and frolic and detour concepts were given new life in a world for which they were never intended.

While the owner consent statutes are a relatively specific statutory response to a well-defined problem, the liability of a master for the torts of his servants is a common-law doctrine which has been explained, attacked and justified on widely differing grounds. Scholars who dislike the doctrine have explained it as left over from medieval notions of the power and responsibilities of the head of a family ${ }^{5}$ or as a blind, unreasoned following of bad dicta. ${ }^{6}$ Judges have resorted to fictions to justify the rule. They have said that master and servant are one in the eyes of the law, or that qui facit per alia facit per se, usually without saying why. Although the master's ability to control the servant is dubious in modern business, he has been held liable because he has the theoretical right of control. However, modern writers have generally stressed three grounds for maintaining the doctrine. ${ }^{7}$ First, if the master is liable for his servants' negligence he will presumably be encouraged to stress safety in the operation of his business. Second, injuries due to negligence are one of the costs of the master's enterprise. Since he is entitled to the profits, he ought to pay all the costs. Third, the damages which the

statute. Compare Norris v. Pacific Indem. Co., 39 Cal. 2d 420, 247 P.2d 1 (1952), with Souza v. Corti, 22 Cal. 2d 454, 139 P.2d 645, (1943). The result in the insurance case is justifiable only if the plaintiff can still recover on the owner's policy by suing the owner under the owner consent statute. In other states, the proper interpretation of these omnibus clauses should depend on whether there is a public policy in favor of allowing injured plaintiffs to recover on the policy, or whether the court sees its job as merely one of interpreting a contract. Some of the difficulties are indicated by Hodge v. Lumbermens Mut. Cas. Co., 203 Va. 275, 123 S.E.2d 372 (1962); Liberty Mut. Ins. Co. v. Stilson, 34 F. Supp. 885 (D. Minn. 1940); Potts v. Farmers' Mut. Auto. Ins. Co., 233 Wis. 313, 289 N.W. 606 (1940).

4 See Collie v. Aust, 173 Cal. App. 2d 793, 342 P.2d 998 (1959). The right of subrogation is specifically provided for by the California statute, but it would seem to exist under tort or agency principles in any case. Kramer v. Morgan, 85 F.2d 96 (2d Cir. 1936).

5 Holmes, Collected Legal Papers 68 (1920).

6 BATY, Vicarious Liability 29 (1916).

7 These theories have been the subject of innumerable writings. See, e.g., Seavey, Speculations as to "Respondeat Superior", in HARvard Legal Essays 433 (1934); Smith, Frolic and Detour, 23 CoLUM. L. REv. 44 (1923). 
master must pay will be reflected in his price for the product or service. The market will then determine whether the benefits of the product or service justify all its costs, including injuries. If the consuming public refuses to buy at a price which will compensate the injuries arising out of the business, then the enterprise which creates the risk of injury will cease.

Superficially the policies behind respondeat superior and the owner consent statutes are parallel. The risk of a business enterprise can be compared to the risk of maintaining an automobile. The statutes should encourage owners to allow only careful drivers to use their vehicles. The effect of the statutes will be to add permittee-caused losses to the cost of automobile ownership through increased insurance premiums. Viewed in this fashion, the statutes appear to be an extension of respondeat superior to automobile owners, and so the relationship has been described by courts and leading authorities. ${ }^{8}$ In fact, however, there are as many differences as similarities, and an ill-considered application by the courts of concepts borrowed from the law of agency has often frustrated the purposes of the statutes.

The requirement of consent has been the major source of confusion. It is understandable that the legislatures did not want to make an owner liable for the negligence of someone who stole his car. ${ }^{9}$ But the requirement of consent has come to mean much more. In the much cited case of Chaika $v$. Vandenberg, ${ }^{10}$ the defendant owner was the father of the driver, who negligently struck the plaintiff in New York City. The defendant testified that he had given his son permission to drive on Long Island, but had specifically forbidden him to drive into the city. The trial judge, directing a verdict for the plaintiff, had found this testimony immaterial, observing: "Where the owner intrusts the car ...

8 "In effect an agency relation is created, which results in vicarious liability." Prosser, Handbook of the Law of Torts 371 (2d ed. 1955). Sometimes the statute itself may suggest that the relationship is one of agency. "[T] he operator thereof shall in case of accident, be deemed to be the agent of the owner . . ." D.C. ConE tit. 40, $\S 424(1961)$. This is not to say, however, that the relationship is in all respects identical to that of master and servant.

9 Lack of a consent requirement caused the Michigan Supreme Court to declare that state's early owner liability statute unconstitutional. Daugherty v. Thomas, 174 Mich. 371,140 N.W. 615 (1913). The statute provided that the owner was to be liable for the negligence of any driver who had not actually stolen the car. The case involved a garage repairman who drove the car a short distance to test it without the owner's express permission. The court found the statute in violation of "natural justice" and due process of law because the owner was made liable when he was in no way at fault. A revised statute which required the owner's consent was upheld, however, in Stapleton v. Independent Brewing Co., 198 Mich. 170, 164 N.W. 520 (1917). The fact that the new statute also provided for liability without fault did not bother the court, since it was felt that the requirement of consent satisfied the dictates of natural justice.

10252 N.Y. 101, 169 N.E. 103 (1929). 
to be used in the business or for the pleasure of the driver, I do not think that violation of restrictions put upon the route to be taken should relieve the owner from liability under the statute."11 The Appellate Division affirmed, but the Court of Appeals ordered a new trial, ruling that the defendant's testimony, if true, should bar recovery. A slight deviation from the terms of the permission might be unimportant, but a deliberate violation of the fundamental terms of a restricted permission relieved the owner of liability.

The reasoning of Chaika $v$. Vandenberg was followed by nearly all the later cases in the jurisdictions having owner consent statutes. ${ }^{12}$ It soon developed into a doctrine of scope of permission, similar to the scope of employment limitation of respondeat superior. It was clear that an owner could not avoid liability for his permittee's negligence by instructing him to drive carefully, any more than a master could claim that his negligent servant was outside the scope of his employment because he had been directed to use due care. ${ }^{13}$ But the cautious owner who limited the time and the place in which the permittee could use his car stood on a better footing, because the permittee who exceeded such limitations was like the servant off on a frolic. ${ }^{14}$ One court went so far as to say that in a master and servant situation, scope of consent means scope of employment.15 Other courts felt that an employee might be within the scope of consent when outside the scope of employment, or within the scope of employment when outside the scope of consent. ${ }^{16}$ At any rate, the effect of the permittee's exceeding permission was the same as that of the servant's exceeding the scope of his employment: It relieved the owner of liability.

Although the parallel was neat, a close look at the underlying policies would have revealed fundamental differences between the enterprise liability of respondeat superior and the instrumentality liability of the owner consent statutes. It is important to realize that respondeat superior was not developed specifically to deal with masters who entrust their servants with potentially dangerous machines. This is well illustrated by

11 Id. at 104, 169 N.E. at 103-04.

12 Henrietta v. Evans, 10 Cal. 2d 526, 75 P.2d 1051 (1988); Kieszkowski v. Odlewany, 280 Mich. 388, 273 N.W. 741 (1937); Truman v. United Prods. Corp., 217 Minn. 155, 14 N.W.2d 120 (1944). But see Scheer v. Rockne Motors Corp., 68 F.2d 942 (2d Cir. 1934), interpreting Ontario law. The law of California today seems unsettled. Compare Garmon v. Sebastian, 181 Cal. App. 2d 454, 5 Cal. Rptr. 101 (1960), with Peterson v. Greiger, Inc., 57 Cal. 2d 43, 367 P.2d 420, 17 Cal. Rptr. 828 (1962).

13 Henrietta v. Evans, supra note 12.

14 Ibid.

15 Kieszkowski v. Odlewany, 280 Mich. 388, 273 N.W. 741 (1937).

16 Hughes v. Quackenbush, 1 Cal. App. 2d 349, 37 P.2d 99 (1934); Moore v. Palmer, 350 Mich. 363, 86 N.W.2d 585 (1957). 
Annis v. Postal Tel. Co., ${ }^{17}$ where the plaintiff was injured in a sidewalk collision with a running telegraph delivery boy. The court held that the telegraph company was liable because the boy was a servant acting within the scope of his employment, even though he had not been provided with a vehicle. The modern policy justification for the result would be that it will encourage the company to select and train more careful delivery boys, that the plaintiff's injury is one of the costs of the company's enterprise, and that the loss can be spread among the company's customers through the price mechanism. Clearly, this enterprise liability theory would not justify holding the company liable if the boy were on a personal errand, or playing baseball in a busy street on his day off. Risks created by such conduct are not a part of the company's enterprise, and there is no more reason to shift the resulting losses to the telegraph company or its customers than to shift them to any other segment of the public. But the liability of the owner of an automobile for the driver's negligence is not based on the driver's being about the owner's business, if so there would be no need for owner consent statutes. The true basis is that the owner has entrusted the driver with a vehicle, and thus given him the power to cause injuries by driving negligently. Even though the driver has been ordered not to go to New York, or to return the car by noon, he has been given the means to cause an injury in Times Square at dusk. The considerations which justify holding the master liable in the Annis case also justify holding the owner of an automobile liable even when the permittee exceeds the "scope of consent"- the Chaika v. Vandenberg situation. First, it is in the public interest to discourage owners from lending their vehicles to careless drivers, whether those drivers obey the terms of their permission or not. Second, one of the risks of permitting another to use an automobile is that he may use it negligently, either inside or outside the scope of permission. If an owner is going to lend his vehicle to others, he should be prepared to accept liability for the harm he thus enables them to cause. Third, the owner can and should protect himself by buying insurance. By this means the harm caused by automobiles is borne, in the form of insurance premiums, by their owners, the class which benefits from their use. Suppose that the young driver in Chaika v. Vandenberg had struck three pedestrians: one on Long Island just after leaving his home, the second in New York City, and the third on Long Island again while returning home. Under the rule of the case, there would certainly be liability for the first, there would certaintly not be liability for the second, and there is no way of telling whether there would be liability for the third. Thus a misapplication of the technicalities of respondeat superior results in decisions which nullify the policy of the statute.

17114 Ind. App. 543, 52 N.E.2d 373 (1944). 
There is another practical argument for following the rule of the trial court rather than the Court of Appeals in Chaika v. Vandenberg. The only testimony offered as to the restriction on permission was the owner's, and it was evidently interested. On retrial it might be corroborated by the son, or other members of the family, but impartial testimony might well be impossible to obtain. There is a real opportunity to exaggerate the definiteness of the restriction on use, if not to commit outright perjury. ${ }^{18}$ If the plaintiff is required to prove that the driver was within the scope of his permission, he may find it impossible to gather the necessary testimony. In Rosenberg $v$. Murray, ${ }^{19}$ the defendant owner received a directed verdict on his own testimony that the driver, his employee, took the vehicle without permission. If the jury is permitted to weigh the testimony's credibility, its decision is apt to be guesswork. The plaintiff's right to recover from the owner may be worth very little if the owner's interested testimony as to the way he remembers the terms of consent is taken seriously.

In view of the easy acceptance of limitations on time and place, it is surprising that the courts had little trouble in finding the owner liable when his permittee entrusted the car to a third person without authorization. This problem was thoroughly and thoughtfully considered by Judge Cardozo in the landmark case of Grant $v$. Knepper, ${ }^{20}$ under both respondeat superior and the New York owner consent statute. The owner had sent out his truck with a driver and a salesman who was not a licensed or competent driver. The salesman prevailed upon the driver to let him take the wheel for a while, and eventually collided with a parked car. Cardozo found the owner liable under two theories. He was liable under respondeat superior because the driver, his employee, was negligent within the scope of his employment in letting an incompetent substitute drive and in not supervising him properly. $\mathrm{He}$ was liable under the owner consent statute because the driver was using the car even when he was not at the wheel. It does not appear from the opinion that this latter holding would be any different if the salesman had been a licensed driver whose negligence was unforeseeable. In effect, Cardozo was simply saying that such a violation of the terms of permission was not enough to save the owner. The California Supreme Court extended this rule in Souza v. Corti, ${ }^{21}$ where the owner loaned his car to his son,

18 See the dissent of Langdon, J., in Henrietta v. Evans, 10 Cal. 2d 526, 75 P.2d 1051 (1938).

19116 F.2d 552 (D.C. Cir. 1940).

20245 N.Y. 158, 156 N.E. 650 (1927).

2122 Cal. 2d 454, 139 P.2d 645 (1943). See also Burgess v. Cahill, 26 Cal. 2d 320, 158 P.2d 393 (1945). For an appreciation of some of the problems this result raises, see Norris v. Pacific Indem. Co., 39 Cal. 2d 420, 247 P.2d I (1952); Collie v. Aust, 173 Cal. 
with instructions not to let anyone else drive it. The son let a friend drive anyway, and an accident followed. There was no evidence that the friend was incompetent or unlicensed, and the son was not in the car at the time of the accident. Nevertheless, the court found that the car was being used with the owner's permission at the time of the accident because the use was within the time, place and purpose of the permission. The son had merely violated a "secret restriction ... on the manner of use ... . Violations of such restrictions may not be said to cause a revocation of the permission."22 Surprisingly, the court reached this conclusion without overruling Henrietta $v$. Evans, ${ }^{23}$ which had adopted the rule of Chaika v. Vandenberg. That case, it said, involved a restriction as to time, place or purpose of use. A restriction as to manner of use was quite a different thing. Telling the driver he may not let anyone else drive is like telling him not to exceed the speed limit. Telling him not to drive to New York is like telling him he may not drive at all.

Souza $v$. Corti stretches the agency-derived theory of scope of consent, but it by no means abandons it. If the father had been an employer and the son an employee, liability could have been founded on respondeat superior as well as on the statute so long as the vehicle was at least arguably on the employer's business. If the court can say that letting a third person drive without authorization is not the kind of deviation that will relieve the owner of liability, it can as easily say that it is not a sufficient deviation from the terms of the employment to relieve the master of liability. ${ }^{24}$ In the Chaika $v$. Vandenberg situation, if the son had been an employee supposedly about his father's business on long Island, his driving to New York could not have been said to be in furtherance of his father's business. It would have been a textbook example of frolic and detour, solidly governed by countless precedents. Liability could not have been founded on respondeat superior. This technical reasoning may explain why the courts came to results which were so inconsistent from the point of view of policy. On any analysis of the policy of the statutes, the results ought to be the same in both kinds of cases. If the policy is to protect plaintiffs who are injured by financially irresponsible drivers, then clearly there should be liability in both. On the other hand, if the policy is to allow owners to protect themselves by reasonable limitations on permission, then a limitation on who is to drive the car is every bit as reasonable as a limitation on

App. 2d 793, 342 P.2d 998 (1959); Rose v. Porter, 101 Cal. App. 2d 333, 225 P.2d 245 (1950).

2222 Cal. 2d at 460-61, 139 P.2d at 648.

23 See cases cited note 12 supra.

24 That was what the court did in Farrell v. Pinson Transfer Co., 293 S.W.2d 170 (Ct. App. Ky. 1956). 
where it is to be driven. Both situations raise the problem of proof: The owner's testimony on the alleged restrictions is likely to be unreliable. The best solution would seem to be that of Carter, J., concurring in Burgess v. Cahill:

If the legislature had intended that the owner should have the right to limit his liability by restricting the operation of such automobile to a specific time or place, it could have so stated, but it did not do so for obvious reasons. The protection which the statute was designed to afford would be clearly reduced by permitting the owner to so limit his liability. The owner can protect himself by insurance against any risk he may assume by permitting the operation of his automobile by third persons, while a victim of the negligent operation of such automobile suffers the same loss whether the automobile is being operated with or without the permission of the owner. ${ }^{25}$

There may also be problems about how the consent was obtained. The driver in Roehrich v. Holt Motor Co. ${ }^{26}$ was an imaginative youth who obtained a car from a dealer by representing himself to be a prospective buyer who wanted to show it to his father before making up his mind. His only intention, in fact, was to have a joy ride. The court found that the youth was not driving with the consent of the owner, because consent obtained by fraud is not consent. It is more like theft. Such reasoning completely misses the point. The owner ought to be liable because he has placed an automobile in the hands of a financially irresponsible person who may drive it negligently, whether he intends to buy it or not. An automobile dealer ought to obtain insurance for the protection of the public if he is going to allow people who represent themselves to be prospective buyers to drive his cars. A California court reached this result when the negligent driver had rented the automobile under a false name. The court held that the name of the driver was immaterial: The fact was that he was entrusted with an automobile. ${ }^{27}$ An even more interesting argument is to be found in Lind v. Eddy. ${ }^{28}$ There the owner was nineteen years old, and claimed that as a minor he was incapable of giving consent, or at least could repudiate it upon reaching twenty-one, thus causing it to vanish as if it had never been. The court sensibly refused to extend its protection of minors to such a case, but said in a dictum that an owner who was really incapable of consent, such as an idiot, would not be liable. It is to be hoped that the courts will not read

2526 Cal. 2d 320, 326, 158 P.2d 393, 396 (1945).

26201 Minn. 586, 277 N.W. 274 (1938).

27 Tuderios v. Hertz Drivurself Stations, Inc., 70 Cal. App. 2d 192, 160 P.2d 554 (1945).

28232 Iowa 1328, 6 N.W.2d 427 (1942). Compare Ridley v. Young, 64 Cal. App. 2d 503, 149 P.2d 76 (1944). 
all the details of the law of contracts into the word "consent." It is hard to believe that the idiot problem is a real one, for one may assume that idiots rarely own automobiles. If one were a titular owner, it might be found that his guardian was the owner for the purpose of the statute. In any case, a minor who is capable of owning and maintaining an automobile ought to be capable of assuming responsibility for its use on the same basis as an adult. ${ }^{29}$

The difficulties discussed so far have arisen, it is submitted, because the courts and the writers have thought of the owner-permittee relationship as an agency relationship, when it is in fact different in important respects. Other aberrations, however, are not so easily explained or excused. For example, the courts had an astonishing difficulty with the word "negligence," as it appeared in the statutes. Many states have automobile guest statutes, which provide that a non-paying passenger who is injured cannot recover from the driver or owner of the vehicle in which he was riding except for "willful misconduct," or some similar form of gross misbehavior. In Payton v. Delnay, ${ }^{30}$ a case arising under such a statute, the attorney for the owner argued that his client was not guilty of willful misconduct simply for lending his car to another. The court saw that that was not the point: Under such reasoning, the owner would never be liable unless he were personally negligent. The point was that the policy of the legislation would be served by interpreting "negligence" to include willful misconduct. It should be stressed that the "willful misconduct" was simply extremely gross negligence; the driver did not intend to injure the plaintiff. It would be a strange policy which said that the owner ought to be liable when his permittee was careless, but not when he was terribly careless. Regrettably, the California Supreme Court had said just that in Weber v. Pinyan.31 An owner was held liable for the driver's negligence, but not for injuries resulting from his "willful misconduct or intoxication," the phrase used in the California guest statute. This result suggests the possibility of an owner escaping liability by proving that his permittee was drunk at the time of the accident! Such results understandably undermine public confidence in the good sense of the judiciary. There is no need to frustrate the policy of the legislature with such a hair-splitting misinterpretation of the legislative intent.

20 Still another problem arises when $A$ lends his car to $B$ who is hit by $C$. In $A$ 's suit against $C$ for damages to the car, should $B$ 's contributory negligence be imputed to $A$ ? A leading case said it should not because the policy of the statute does not apply to contributory negligence. Mills v. Gabriel, 284 N.Y. 751, 31 N.E.2d 512 (1940). Compare Stuart v. Pilgrim, 247 Iowa 709, 74 N.W.2d 212 (1956), reaching the opposite result.

30348 Mich. 238, 83 N.W.2d 204 (1957).

319 Cal. 2d 226, 70 P.2d 183 (1937). 
The point about willful misconduct can be carried a step further, to the case of a driver who deliberately runs down a victim in order to kill him. Under agency theory, there should be no liability unless the killing was done to accomplish a result within the scope of employment. ${ }^{32}$ Although research has disclosed no cases under the owner consent statutes in which willful killing has actually occurred, presumably the courts would say that the statute makes the owner liable only for the driver's negligence, and although that term may include willful and wanton misconduct, it does not include deliberate attempts at murder. This would no doubt be entirely correct as a piece of statutory interpretation, but there is nothing to the logic of owner liability which ought to prevent the legislature from extending liability to the owner in the willful murder situation. Public policy is surely in favor of discouraging owners from lending their vehicles to murderers or maniacs, and the owner who does lend to a murderer or maniac has given him a power to cause injury that he would otherwise not have. The victim or his family certainly deserves the protection of the owner's insurance policy just as much as the victim of the merely negligent driver.

The principal objection to extending the liability of the owner under the statutes to its logical limits is that such an extension will have harsh effects on owners who are themselves not at fault and are inadequately insured. Such a fear led the Michigan Supreme Court to.hold that state's early owner's liability statute unconstitutional. ${ }^{33}$ The fact is that the owner consent statutes, like respondeat superior, are designed to fasten liability where there is no fault, as a means of shifting the burden of injuries onto those best able to bear it. The way for an owner to protect himself is either by purchasing insurance or by refusing to let others use his vehicle, not by leaving the loss on the innocent victim.

Perhaps the reason the courts have had such difficulty in discarding outworn concepts is that the legislatures have chosen to make modifications within the traditional system of automobile tort liability rather than to make fundamental changes. The arguments used to justify the owner consent statutes could also be used to justify statutes making owners liable for all harm caused by their vehicles whether driven by the owner, his permittee or a thief, and whether the driver was negligent or not. The owner consent statutes form a small island of a new kind of liability in a sea of negligence and agency law. It is understandable that the courts have resorted to traditional concepts in interpreting them, for the legislature has not made a clear choice between the old and the new. But legislative schizophrenia should not blind the courts to the important differences between enterprise and instrumentality liability.

32 Restatement, Agency § 245 (1933).

33 Daugherty v. Thomas, 174 Mich. 371, 140 N.W. 615 (1913). 